Tomoki Nishiyama MD PhD

\title{
Interaction among NMDA receptor-, NMDA glycine site- and AMPA receptor antago- nists in spinally mediated analgesia
}

Purpose: The NMDA (N-methyl-D-aspartate) receptor antagonists and the NMDA glycine site antagonists given alone have minimal effects on acute nociception. In contrast, the AMPA (alpha-amino-3-hydroxy-5-methylisoxazole-4-propionic acid) receptor antagonists have a major role in acute nociception. We investigated the interactions among these three antagonists in acute nociception.

Methods: Sprague-Dawley rats (250-300 g) were implanted with chronic lumbar intrathecal catheters and were tested for their thermal withdrawal response using the hot plate test after intrathecal administration of AP-5 (NMDA receptor antagonist), ACEA I 02I (NMDA glycine site antagonist), or ACEA 2085 (AMPA receptor antagonist). The combinations of these three agents were also tested.

Results: Intrathecal administration of ACEA 2085 had a dose dependent analgesic effect while intrathecal AP-5 or ACEA 1021 could not induce dose dependent effect. Co-administration of AP-5 I0 $\mu \mathrm{g}$ and ACEA 2085 intrathecally showed no changes in the thermal response latency compared with ACEA 2085 alone. ACEA I02I, $12 \mu \mathrm{g}$, and AP-5 showed left-ward shift of the dose effect curve only with small doses of AP-5 (I $\mu \mathrm{g}, 3 \mu \mathrm{g})$. Only the smallest dose of ACEA 2085 (0.1 ng) with ACEA I02I I $2 \mu \mathrm{g}$ induced antinociception compared with that of ACEA 2085 alone.

Conclusions: The combination of the NMDA glycine site antagonist and low doses of the NMDA receptor antagonist or the AMPA receptor antagonist increased the analgesic effect on acute thermal nociception with increased side effects, while the NMDA receptor antagonist and the AMPA receptor antagonist had no such interaction.

Objectif : Les antagonistes des récepteurs NMDA (N-méthyl-D-aspartate) et les antagonistes NMDA au site glycine administrés seuls ont des effets minimaux sur la nociception aiguë. Par ailleurs, les antagonistes des récepteurs AMPA (acide alpha-amino-3-hydroxy-5-méthylisoxazole-4-propionique) ont un rôle majeur dans la nociception aiguë. Nous avons examiné les interactions entre trois antagonistes dans la nociception aiguë.

Méthode : On a implanté à demeure un cathéter intrathécal lombaire chez des rats Sprague-Dawley (250-300 g) et on a vérifié la réaction de retrait d'une source de chaleur, en utilisant la technique de la plaque chauffante, à la suite de l'administration intrathécale de AP-5 (antagoniste des récepteurs NMDA), d'ACEA I02 I (antagoniste NMDA au site glycine) ou ACEA 2085 (antagoniste des récepteurs AMPA). Les combinaisons de ces trois agents ont aussi été vérifiées.

Résultats : L'administration intrathécale d'ACEA 2085 a produit un effet dose-dépendant, mais non l'AP-5 intrathécal ou l'ACEA I02 I. La co-administration de $10 \mu \mathrm{g}$ d'AP-5 et d'ACEA 2085 intrathécale n'a pas provoqué de modification du temps de latence de réaction à la chaleur comparée à l'administration d'ACEA 2085 seul. L'ACEA 102I, $12 \mu \mathrm{g}$, et l'AP-5 ont montré un déplacement vers la gauche de la courbe dose-effet pour de faibles doses seulement d'AP-5 (I $\mu \mathrm{g}, 3 \mu \mathrm{g})$. Seule la plus petite dose d'ACEA 2085 (0, I ng) avec I2 $\mu$ g d'ACEA I02 I ont induit un effet antinociceptif quand on les compare à l'ACEA 2085 employé seul.

Conclusion : La combinaison d'antagoniste NMDA au site glycine et de faibles doses d'antagoniste des récepteurs NMDA ou d'antagoniste des récepteurs AMPA augmente l'effet analgésique sur la nociception aiguë à la chaleur et s'accompagne d'effets secondaires plus importants. L'antagoniste des récepteurs NMDA et l'antagoniste des récepteurs AMPA ne présentent pas cette interaction.

From the Department of Anesthesiology, The University of Tokyo, Tokyo, Japan.

Address correspondence to: Tomoki Nishiyama MD PhD, 3-2-6-603, Kawaguchi, Kawaguchi-shi, Saitama, 332- 0015, Japan.

Phone: 81-3-5800-8668; Fax: 81-3-5800-8938; E-mail: NISHIYAMAT-ANE@h.u-tokyo.ac.jp

Accepted for publication April 8, 2000. 
I

$\mathrm{N}$ the spinal cord, glutamate has an important role in nociceptive processing and there are two types of glutamate receptors; N-methyl-Daspartate (NMDA) and non-NMDA receptors. The latter includes alpha-amino-3-hydroxy-5methylisoxazole-4-propionic acid (AMPA) and kainate subtype of receptors. The NMDA receptors mediate a polysynaptic excitation, while AMPA receptors mediate a monosynaptic excitation of second order neurons. ${ }^{1,2}$ The NMDA glycine site is a regulatory site on the NMDA receptor responsible for modulation of receptor function by endogenous substances. ${ }^{3}$

Correspondingly, NMDA antagonists have little effect on acute nociception, but are effective in facilitated states of nociceptive processing. ${ }^{4,5}$ The NMDA glycine site antagonist also blocks facilitation of nociceptive transmission. ${ }^{3}$ In contrast, AMPA receptor antagonists have analgesic effects on acute nociception..$^{6,7}$

The NMDA receptors and AMPA receptors are often co-localized on the post-synaptic membrane at the same synapse in rat hippocampus. ${ }^{8}$ The NMDA receptor antagonists and AMPA receptor antagonists have a supra- additive neuroprotective effect against hypoxic damage in the brain. ${ }^{9}$ This observation suggests a functional interaction in the brain between the NMDA and the AMPA receptor systems. However, there have been few data on the anatomical or functional interaction between the NMDA and the AMPA receptor systems in the spinal cord as related to nociception.

The NMDA glycine site antagonists administered intrathecally attenuate NMDA produced facilitation of nociception. ${ }^{3}$ This suggests that the glycine site is necessary in conjunction with the NMDA ionophore for facilitation of nociception in the spinal cord. Yet, there are no studies of the interaction in antinociceptive effects between the NMDA receptor antagonist and the NMDA glycine site antagonist.

Considering this evidence, we would expect some interaction in the effects on facilitated nociceptive processing but not on acute nociception among NMDA and AMPA receptor antagonists and NMDA glycine site antagonists.

The purpose of this study was to investigate the spinally mediated antinociceptive interaction among NMDA receptor antagonists, NMDA glycine site antagonist, and AMPA receptor antagonists on acute noxious stimulation to elucidate functional coupling in the nociception of different glutamate receptors in the spinal cord, as well as to investigate the interaction with respect to side effects.
Methods

\section{Animal preparations}

Experiments were carried out according to a protocol approved by the Institutional Animal Care Committee of the University of California, San Diego. Sprague-Dawley rats (250-300g; Harlan Industries, Indianapolis, IN) were implanted with chronic lumbar intrathecal catheters under halothane (2\%) anesthesia according to a modification of the method described by Yaksh and Rudy. ${ }^{10}$ Briefly, an $8.5 \mathrm{~cm}$ polyethylene (PE-10; Clay Adams, Parsippany, NJ) catheter was advanced caudally through an incision in the atlanto-occipital membrane, to the thoracolumbar level of the spinal cord. The external part of the catheter was tunneled subcutaneously to exit on top of the skull and plugged with a steel wire. Rats with normal motor function and behaviour were used five to seven days after surgery. Rats with normal motor function were used three times, with an inter-test interval of at least five days.

\section{Drugs and injection}

Drugs for intrathecal injection were dissolved in solvent such that $10 \mu \mathrm{l}$ contained the desired quantity of the agent. The ACEA 2085 (AMPA receptor antagonist; CoCensys, Inc., Irvine, CA) and AP-5 (( \pm )-2-amino-5phosphonopentanoic acid, NMDA receptor antagonist; Research Biochemical International, Natick, MA) were dissolved in normal saline and ACEA 1021 (5-nitro-6,7dichloro-2,3-quinoxaline dion, non-strychnine-sensitive NMDA glycine site antagonist; Eagle-Picher Industries, Lenexa, KS) was dissolved in vehicle (tris buffer). After intrathecal drug injection, the catheter was flushed by injection of $10 \mu \mathrm{l}$ of normal saline (saline, ACEA 2085, and AP-5 groups) or vehicle (vehicle and ACEA 1021 groups). A micro injector syringe was used for all injections. In each dose group, 10 rats randomly received one of these doses of ACEA 2085 (0.1 ng, $10 \mathrm{ng}, 500 \mathrm{ng}$, $750 \mathrm{ng})$, AP-5 (1 $\mu \mathrm{g}, 3 \mu \mathrm{g}, 10 \mu \mathrm{g}, 30 \mu \mathrm{g})$, ACEA $102 \mathrm{l}(2.4 \mu \mathrm{g}, 8 \mu \mathrm{g}, 12 \mu \mathrm{g}, 24 \mu \mathrm{g})$, saline or vehicle. The saline and vehicle groups were the control groups.

\section{Nociceptive test}

All animals were tested for acute nociceptive response using a hot-plate test. ${ }^{11}$ The rats were placed on a surface maintained at $52.0 \pm 0.5^{\circ} \mathrm{C}$ and enclosed by Plexiglas walls. The behavioural endpoint was taken as licking of one hind paw or, less frequently, the jumping off of the plate. The cut-off time in the absence of a response was $60 \mathrm{sec}$ to prevent tissue injury.

\section{Behavioural and motor function test ${ }^{1}$}

The general behaviour (including agitation and allodynia), motor function, flaccidity, pinna reflex, and 


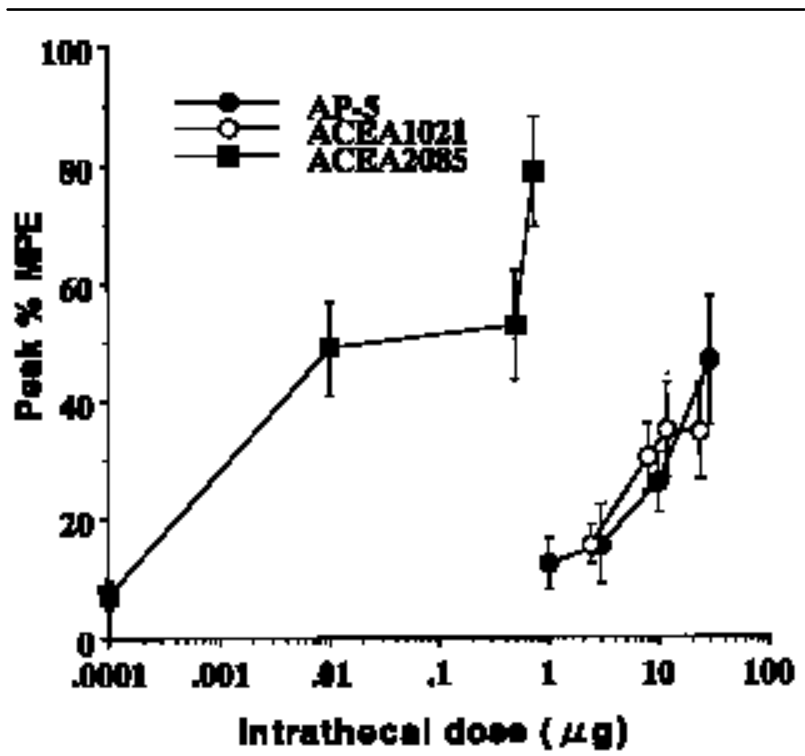

FIGURE 1 Dose response curves of the peak \% MPE for intrathecal AP-5 (NMDA receptor antagonist), ACEA 1021 (NMDA glycine site antagonist), and ACEA 2085 (AMPA receptor antagonist). Each point presents the mean \pm SEM of 10 animals.

corneal reflex were examined. They were judged as present or absent. Agitation was judged as spontaneous irritable movement and/or vocalization. The presence of allodynia was examined by looking for agitation (escape and/or vocalization) evoked by lightly stroking the flank of the rat with a small probe. Motor function was evaluated by the placing/stepping reflex and the righting reflex. The former was evoked by drawing the dorsum of either hind paw across the edge of the table. Normally rats try to put the paw ahead to walk. The latter was assessed by placing the rat horizontally with its back on the table, which normally gives rise to an immediate, coordinated twisting of the body to an upright position. Disturbance of the righting reflex also implies central nervous system damage. Flaccidity was judged as muscle weakness. Pinna and corneal reflexes were examined with a paper string. When a paper string was put into the ear canal or touched the cornea rats normally shake their head or blink, respectively, to avoid the stimulation.

\section{Experimental paradigm}

Dose effect relationship: The first series of experiments was performed to determine the dose-dependency and time course of the analgesic actions of intrathecally administered ACEA 2085, ACEA 1021, and AP-5 on acute thermal nociception. The hot-

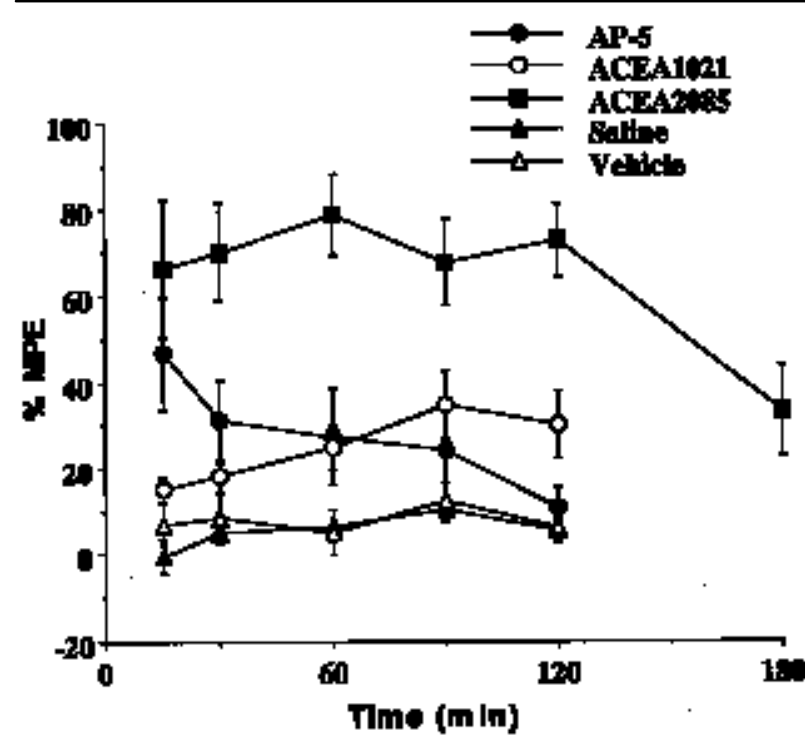

FIGURE 2 Time course of the effects of intrathecal saline, vehicle, AP-5 $30 \mu \mathrm{g}$ (NMDA receptor antagonist), ACEA $102124 \mu \mathrm{g}$ (NMDA glycine site antagonist), and ACEA $2085750 \mathrm{ng}$ (AMPA receptor antagonist). These doses were the usable maximum doses. Each point represents the mean \pm SEM of 10 animals.

plate, behavioural and motor function tests were performed before and at intervals of 15, 30, 60, 90, and 120 min (until 180 min for ACEA 2085) after the injection. In each group, 10 rats were tested.

The ACEA 1021 and AP-5 could not produce a response sufficient to allow calculation of a $50 \%$ effective dose $\left(\mathrm{ED}_{5}\right)$. Therefore, to investigate the interaction between the two agents, a fixed dose of ACEA $1021(12 \mu \mathrm{g})$ was co-administered with various doses of ACEA 2085 or AP-5 and AP-5 (10 $\mu \mathrm{g})$ with various doses of ACEA 2085 was also tested. The higher doses of ACEA 1021 and AP-5 were considered not to be usable because of behavioral side effects. In each group, eight rats were tested.

\section{Data analysis and statistics}

Response latency (sec.) data from hot plate measurements were converted to a percentage of the maximum possible effect (\%MPE) according to the formula: $\% \mathrm{MPE}=[$ (postdrug latency - base line latency) / (cutoff time - base line latency)] x100. ${ }^{11,12}$

Data were expressed as mean \pm standard error $($ SEM) due to the small number of rats in each group. The statistical analysis was done only for comparable doses with two way analysis of variance (ANOVA) followed by a post-hoc Contrast analysis if appropriate. A $P$ value less than 0.05 was considered statistically significant. 


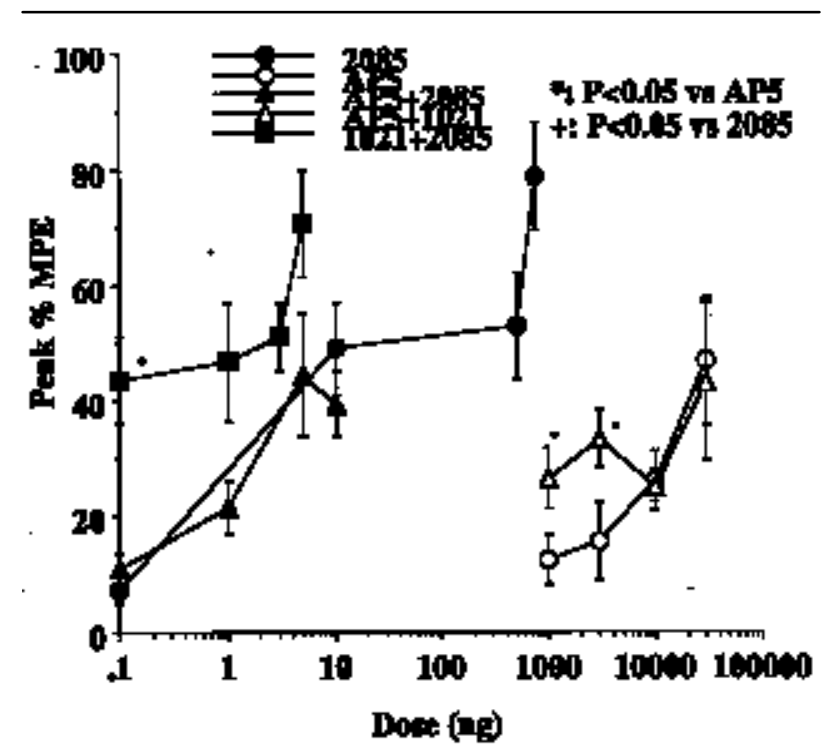

FIGURE 3 Interaction between AP-5 and ACEA 2085, AP-5 and ACEA 1021, or ACEA 1021 and ACEA 2085 shown by the peak \% MPE. X axis indicates intrathecal dose of ACEA 2085 for the figures of 2085, AP5 +2085 , and $1021+2085$, AP- 5 for the figures of AP5 and AP5 + 1021. Each point represents the mean \pm SEM of 8 animals.

Results

Analgesic effects of each agent

Baseline latency was $6.8 \pm 0.1$ (SEM) sec. (range: 5.5 to $8.0 \mathrm{sec}$ ).

Intrathecal administration of AP-5 (NMDA receptor antagonist), ACEA 1021 (NMDA glycine site antagonist), and ACEA 2085 (competitive AMPA receptor antagonist) resulted in dose-dependent increases in the thermal response latency (Figure 1). The maximum usable dose of AP-5 or ACEA 1021 did not induce an effect of more than 50\% MPE (Figure 2). The rank order of potency was ACEA $2085>$ ACEA $1021=$ AP-5 $($ Figure 1$)$.

\section{Interaction among glutamate receptor antagonists}

Co-administration of AP-5 $10 \mu \mathrm{g}$ and ACEA 2085 intrathecally showed no changes in the thermal response latency compared with ACEA 2085 alone. A dose of more than 10 ng ACEA 2085 was not used in the combination treatment because the combination induced severe motor disturbance and flaccidity in all rats in the preliminary study. The ACEA $102112 \mu \mathrm{g}$ and AP-5 showed an increase of peak \% MPE only with small doses of AP-5 ( $1 \mu \mathrm{g}$ and $3 \mu \mathrm{g}$ ). Only the smallest dose of ACEA 2085 (0.1 ng) with ACEA
$102112 \mu \mathrm{g}$ induced an increase of peak \% MPE compared with ACEA 2085 (0.1 ng) alone (Figure 3).

\section{Behaviour and motor function (Table)}

Agitation or allodynia increased with ACEA 102124 $\mu \mathrm{g}$ or ACEA $2085750 \mathrm{ng}$ compared to the control. Motor disturbance (tested by the placing/stepping reflex and the righting reflex) was seen with higher doses of ACEA $102112 \mu \mathrm{g}$, ACEA $208510 \mathrm{ng}$, or AP-5 $3 \mu \mathrm{g}$. Flaccidity occurred in rats who received ACEA 2085 at $10 \mathrm{ng}$ or more and in those with AP$530 \mu \mathrm{g}$. ACEA $102112 \mu \mathrm{g}$ or more induced loss of pinna reflex. No rats showed loss of corneal reflex in the present study.

In the combination drug studies, AP-5 $10 \mu \mathrm{g}+$ ACEA 2085 increased the frequency of motor disturbance and flaccidity compared to AP-5 or ACEA 2085 alone. Flaccidity also increased with the combination of ACEA $102112 \mu \mathrm{g}$ and AP-5 compared with each agent alone.

\section{Discussion}

This study shows that the combination of the NMDA glycine site antagonist (ACEA 1021) and low, but not high, doses of the NMDA receptor antagonist (AP-5) or the AMPA receptor antagonist (ACEA 2085) increased analgesic effect on acute thermal nociception compared with each agent alone. The NMDA receptor antagonist and the AMPA receptor antagonist had no such interaction. The combination increased motor disturbance and flaccidity.

The NMDA antagonists have been reported to have little effect on acute nociception,,${ }^{4}{ }^{5}$ because acute nociception is considered to be mediated by monosynaptic transmission in the spinal cord. ${ }^{13}$ The NMDA glycine site has an important role in the activation of the NMDA channel by glutamate. ${ }^{3}$ Thus, the functional properties of the NMDA glycine site antagonist resemble those of NMDA antagonists. These are consistent with the present results in which AP-5 and ACEA 1021 had no analgesic effects on thermally evoked nociception. In contrast, the AMPA receptors mediate acute excitation from primary afferent fibers to dorsal horn neurons. ${ }^{6}$ The AMPA receptor antagonist has an antinociceptive effect on acute thermal stimulus ${ }^{14}$ as ACEA 2085 in the present study.

From these previous observations, the NMDA receptor antagonist or the NMDA glycine site antagonist seem to have no spinally mediated analgesic interaction with the AMPA receptor antagonist on acute nociception. While the NMDA receptor antagonist (AP-5) had no interaction with the AMPA receptor antagonist (ACEA 2085), the NMDA glycine site 
TABLE Side effects of intrathecal administration of each agent and their combinations

\begin{tabular}{|c|c|c|c|c|c|}
\hline & & Agitation and/or Allodynia & Motor Disturbance & Flaccidity & Loss of Pinna Reflex \\
\hline Saline & & 20 & 0 & 0 & 0 \\
\hline Vehicle & & 50 & 0 & 0 & 0 \\
\hline \multirow[t]{2}{*}{ AP-5 } & $3 \mu \mathrm{g}$ & 10 & 10 & 0 & 0 \\
\hline & $10 \mu \mathrm{g}$ & 10 & 30 & 0 & 0 \\
\hline \multicolumn{6}{|l|}{ ACEA 1021} \\
\hline ACFA 2085 & $12 \mu \mathrm{g}$ & 50 & 20 & 0 & 10 \\
\hline & $10 \mathrm{ng}$ & 0 & 10 & 10 & 0 \\
\hline & $100 \mathrm{ng}$ & 20 & 30 & 30 & 0 \\
\hline \multicolumn{6}{|l|}{$\begin{array}{l}\text { AP-5 } 10 \mu \mathrm{g}+ \\
\text { ACEA } 2085\end{array}$} \\
\hline & $1 \mathrm{ng}$ & 0 & 50 & 25 & 0 \\
\hline & $10 \mathrm{ng}$ & 12.5 & 87.5 & 75 & 0 \\
\hline ACEA 1021 & $12 \mu g_{+}$ & & & & \\
\hline \multirow[t]{2}{*}{ ACEA 2085} & $10 \mathrm{ng}$ & 25 & 12.5 & 12.5 & 0 \\
\hline & $100 \mathrm{ng}$ & 12.5 & 37.5 & 25 & 0 \\
\hline ACEA 1021 & $12 \mu \mathrm{g}+$ & & & & \\
\hline \multirow[t]{2}{*}{ AP-5 } & $3 \mu \mathrm{g}$ & 0 & 12.5 & 12.5 & 0 \\
\hline & $10 \mu \mathrm{g}$ & 0 & 25 & 25 & 0 \\
\hline
\end{tabular}

The numbers show the $\%$ of rats with each side effects. Total number of rats in each dose group is 8 or 10 . Motor disturbance includes the placing and stepping reflex and the righting reflex.

antagonist (ACEA 1021) intensified the antinociceptive effect of the AMPA receptor antagonist.

In the brain, AMPA receptors are co-localized with NMDA receptors. Synaptically released glutamate causes rapid activation of both AMPA and NMDA receptors, resulting in a dual synaptic response. ${ }^{15}$ The NMDA receptor antagonists inhibit calcium ion $\left(\mathrm{Ca}^{2+}\right)$ entry through the receptor -operated $\mathrm{Ca}^{2+}$ ionophore. ${ }^{16}$ The AMPA receptor antagonists inhibit $\mathrm{Ca}^{2+}$ entry through the NMDA receptor/ion channel, the voltage-operated $\mathrm{Ca}^{2}+$ channel and the sodium ion $\left(\mathrm{Na}^{+}\right) / \mathrm{Ca}^{2}+$ exchanger. The AMPA receptor antagonists suppress $\mathrm{Na}^{+}$- and potassium ion $(\mathrm{K})$ - mediated cell depolarization, and therefore prevent the opening of voltage-operated $\mathrm{Ca}^{2+}$ channels. ${ }^{17}$ Thus, NMDA receptor antagonists and the AMPA receptor antagonists can act synergistically by blocking the interacting mechanisms of $\mathrm{Ca}^{2+}$ entry in the brain. For focal or global brain ischemia, combined treatment of the NMDA receptor antagonist and the AMPA receptor antagonist could decrease the infarct size or the incidence of damaged cells more than a single treatment. ${ }^{9}$ When low doses of the AMPA receptor antagonist were co-administered with NMDA receptor antagonists systemically, an interaction in decreasing the minimum alveolar concentration of halothane between the two antagonists was evident. ${ }^{8}$ This interaction between the two glutamate receptor antagonists was obvious when subanesthetic doses of the antagonists were combined. However, there is little evidence to suggest the interaction between the AMPA receptor and the NMDA receptor in the spinal cord, especially regarding nociceptive mechanisms.

The present study, however, showed that a low dose of NMDA glycine site antagonist had an interaction with the AMPA receptor antagonist in the spinal cord. The reason why the low doses of NMDA glycine site antagonist had interactions with the NMDA or AMPA antagonists might be 1) The effects of high doses might be masked by side effects, or 2) The participation of each glutamate receptor on acute nociception is limited by a ceiling effect. Regarding side effects, motor disturbance and flaccidity were not so severe as to inhibit the paw movement. In addition, if the disturbance was severe enough to block the response, higher doses of the combination would be expected to have a greater improvement. For these reasons, side effects might not cause this discrepancy. Therefore a ceiling effect might be the reason why the interactions were not dose dependent.

In conclusion, the combination of the NMDA glycine site antagonist and low doses of the NMDA receptor antagonist or the AMPA receptor antagonist had significant interactions in terms of their analgesic effects on acute thermal nociception, while the NMDA receptor antagonist and the AMPA receptor antagonist showed no such interaction. 
Acknowledgment

I would like to thank Professor Tony L. Yaksh, Anesthesiology Research Laboratory, University of California San Diego for his support of this study.

\section{References}

1 Dickenson $A H$ A cure for wind-up: NMDA receptor antagonists as potential analgesics. Trends Pharmacol Sci 1990; 11: 307-9.

2 Headley PM, Grillner S. Excitatory amino acids and synaptic transmission: the evidence for a physiological function. Trends Pharmacol Sci 1990; 11: 205-11.

3 Kolhekar R, Meller ST, Gebhart GF. N-methyl-D-aspartate receptor-mediated changes in thermal nociception: allosteric modulation at glycine and polyamine recognition sites. Neuroscience 1994; 63: 925-36.

4 Haley JE, Sullivan AF, Dickenson AH. Evidence for spinal $N$-methyl-D-aspartate receptor involvement in prolonged chemical nociception in the rat. Brain Res 1990; 518: 218-26.

5 Näsström J, Karlsson U, Post C. Antinociceptive actions of different classes of excitatory amino acid receptor antagonists in mice. Eur J Pharmacol 1992; 212: 21-9.

6 Dougherty PM, Palecek J, Paleckova V, Sorkin LS, Willis $W D$. The role of NMDA and non-NMDA excitatory amino acid receptors in the excitation of primate spinothalamic tract neurons by mechanical, chemical, thermal and electrical stimuli. J Neurosci 1992; 12 : 3025-41.

7 Hunter JC, Singh L. Role of excitatory amino acid receptors in the mediation of the nociceptive response to formalin in the rat. Neurosci Lett 1994; 174: 217-21.

8 Bekkers JM, Stevens CF. NMDA and non-NMDA receptors are co-localized at individual excitatory synapses in cultured rat hippocampus. Nature 1989; 341: 230-3.

9 Lippert K, Welsch M, Krieglstein J. Over-additive protective effect of dizocilpine and NBQX against neuronal damage. Eur J Pharmacol 1994; 253: 207-13.

10 Yaksh TL, Rudy TA. Chronic catheterization of the spinal subarachnoid space. Physiol Behav 1976; 17: 1031-6.

11 Malmberg AB, Yaksh TL. Isobolographic and doseresponse analyses of the interaction between inthathecal mu and delta agonists: effects of naltrindole and its benzofuran analog (NTB). J Pharmacol Exp Ther 1992; 263: 264-75.

12 Nishiyama T, Yaksh TL, Weber E. Effects of intrathecal NMDA and non-NMDA antagonists on acute thermal nociception and their interaction with morphine. Anesthesiology 1998; 89: 715-22.

13 Davies J, Watkins JC Role of excitatory amino acid receptors in mono- and polysynaptic excitation in the cat spinal cord. Exp Brain Res 1983; 49: 280-90.
14 Advokat C, Rutherford D. Selective antinociceptive effect of excitatory amino acid antagonists in intact and acute spinal rats. Pharmacol Biochem Behav 1995; 51: 855-60.

15 Buchanan JT, Brodin L, Dale N, Grillner S. Reticulospinal neurones activate excitatory amino acid receptors. Brain Res 1987; 408: 321-5.

$16 \mathrm{Kemp} J A$, Foster AC, Wong EHF. Non-competitive antagonists of excitatory amino acid receptors. Trends Neurosci 1987; 10: 294.

17 Murphy SN, Miller RJ. Regulation of $\mathrm{Ca}^{++}$influx into striatal neurons by kainic acid. J Pharmacol Exp Ther 1989; 249: 184-93.

18 McFarlane C, Warner DS, Dexter F. Interactions between NMDA and AMPA glutamate receptor antagonists during halothane anesthesia in the rat. Neuropharmacology 1995; 34: 659-3. 